J. Gen. Appl. Microbiol
Vol. 9, No. 3, 1963 .

\title{
TRANSDUCTION AND TRANSFORMATION BETWEEN BACILLUS SUBTILIS AND BACILLUS NATTO
}

\author{
HATSUO AOKI ${ }^{1}$, HIUGA SAITO, and YONOSUKE IKEDA \\ Institute of Applied Microbiology, University of Tokyo, Tokyo \\ Received July 10, 1963
}

A group of aerobic spore-bearing bacilli which have long been used in this country as fermenters in manufacturing "natto" was named "Bacillus natto" by SAwAmURA (1) in 1879, and it comprises a variety of strains whose taxonomic features are not sharply distinguishable from those of other aerobic spore bearers. Current studies on the biochemical as well as genetic relationship between $B$. subtilis and $B$. natto have revealed that those two bacilli should be considered as one species. For instances, Marmur et al. $(2,3)$ reported the success of DNA hybrid formation between the two species and also described the transfer of genetic traits from $B$. natto to $B$. subtilis by DNA.

To make this point clearer, the authors attempted to employ the phage mediated transduction technique established by Thorne (4) and TAKahashi (5) in $B$. subtilis as well as the transformation technique established by SPIzizen (6). The experiments were done between $B$. subtilis and several strains of $B$. natto. The DNA composition of these bacilli and the transducing phage will be the subject of subsequent publications.

\section{MATERIALS AND METHODS}

Bacterial strains. Seven strains of B. natto listed in Table 1 were used. They were stock cultures at the Institute of Applied Microbiology, University of Tokyo. Strains 1212-52 $\left(\mathrm{rry}^{-}\right)$and 1259-87 $\left(\mathrm{arg}^{-}\right)$were derived from strains 1212 and 1259 , respectively, by $\mathrm{X}$ ray irradiation. Strain 23 is a wild type strain of B. subtilis Marburg. Strain 171-15 (try- $\left.a r g^{-}\right)$was derived from B. subtilis Marburg $160($ try-).

Bacteriophage. S-l is a temperate phage, isolated by TAKAGI $(\boldsymbol{y})$, which is capable of transducing genetic traits from $B$. subtilis 23 to auxotrophic mutants. The phage titer was assayed by the agar layer method using strain 23 as an indicator.

Media. NB broth: containing per liter of distilled water, Bacto nutrient broth, $14 \mathrm{~g}$; Bacto peptone, $7 \mathrm{~g}$; Bacto yeast extract, $4 \mathrm{~g}$; and glucose, $1 \mathrm{~g}$. Minimal medium : containing per liter of water, $\mathrm{K}_{2} \mathrm{HPO}_{4}, 7 \mathrm{~g} ; \mathrm{KH}_{2} \mathrm{PO}_{4}, 3 \mathrm{~g}$; $\mathrm{Na}_{3}$-citrate $\cdot 2 \mathrm{H}_{2} \mathrm{O}, 0.5 \mathrm{~g} ;\left(\mathrm{NH}_{4}\right)_{2} \mathrm{SO}_{4}, 1 \mathrm{~g} ; \mathrm{MgSO}_{4} \cdot 7 \mathrm{H}_{2} \mathrm{O}, 0.2 \mathrm{~g}$; and glucose, $5 \mathrm{~g}$. Glucose and $\mathrm{MgSO}_{4} \cdot 7 \mathrm{H}_{2} \mathrm{O}$ were autoclaved separately. Supplemented medium: for the detection of transductants and transformants, the minimal medium

1 Present address : Fujisawa Pharmaceutical Industries, Ltd., Koganei City, Tokyo. 
was supplemented with one of the following amino acids, L-tryptophan $50 \mu \mathrm{g} / \mathrm{ml}$ and L-arginine $100 \mu \mathrm{g} / \mathrm{ml}$.

Transduction experiment. For the preparation of phage suspension, a strain of $B$. natto or $B$. subtilis was lysogenized with phage S-l and cultivated overnight in $\mathrm{NB}$ broth at $37^{\circ}$. The cells were centrifuged at $12,000 \mathrm{rpm}$ for $15 \mathrm{~min}$. The suspension thus prepared contained about $10^{9}$ per $\mathrm{ml}$ of infective phages in the case of $B$. subtilis. The titer was generally low when the phage multiplied in strains of $B$. natto. Recipient cells were cultivated in NB broth overnight at $37^{\circ}$, and after dilution to one twentieth with fresh $\mathrm{NB}$ broth incubated further for $3 \mathrm{hr}$ to gain $5-6 \times 10^{8} / \mathrm{ml}$ of cells.

One $\mathrm{ml}$ of the recipient cell suspension and $0.1 \mathrm{ml}$ of the phage suspension were mixed together and kept at $37^{\circ}$ for 15 min with shaking. The mixture was diluted with $10 \mathrm{ml}$ of chilled saline $(0.85 \%)$ and centrifuged. The cells were suspended in one $\mathrm{ml}$ saline and $0.1 \mathrm{ml}$ was plated on an appropriate agar medium prepared for the detection of transductants. Colonies were counted after 2 days' incubation at $37^{\circ}$.

Transformation experiment. Transforming DNA was prepared from the cells of $B$. natto by the method described by SAITo and MiUra (8). The conditions employed for the performance of transformation were the same as those described previously $(6,9)$.

\section{RESULTS}

Plating efficiencies of phage $S-1$ on $B$. natto

To know the plating efficiencies of phage S-l on different strains of $B$. natto, aliquots containing equal numbers of phage particles were plated with preincubated cells. Table 1 shows the relative numbers of plaques appeared on each strain. Generally speaking, the efficiencies on strains of $B$. natto were lower than that on the standard strain, B. subtilis 23.

Table 1. Plating efficiencies of phage S-1 on strains of $B$. natto.

\begin{tabular}{|c|c|c|c|}
\hline & Strain & E.O.P $a$ of Phage S-1 & Requirement \\
\hline \multirow[t]{9}{*}{ B. natto } & 1028 & $6.6 \times 10^{-1}$ & Not determined \\
\hline & 1212 & $2.8 \times 10^{-1}$ & None \\
\hline & 1151 & $2.7 \times 10^{-1}$ & Biotin \\
\hline & 1259 & $4.7 \times 10^{-1}$ & None \\
\hline & 1143 & $1.9 \times 10^{-5}$ & Biotin \\
\hline & 1109 & $1.6 \times 10^{-1}$ & Not determined \\
\hline & 1163 & $1.7 \times 10^{-2}$ & " \\
\hline & $1212-52$ & - & Tryptophan \\
\hline & $1259-87$ & - - - & Arginine \\
\hline \multicolumn{2}{|c|}{ B. subtilis $171-15\left(\operatorname{trg}_{160} \arg _{171}\right)$} & 0 & Tryptophan \& arginine \\
\hline$" \prime$ & 23 & 1.0 & None \\
\hline
\end{tabular}

\footnotetext{
a Efficiency of plating.
} 
Transduction from $B$. natto to $B$. subtilis

As seen in Table 2, 5 out of the 7 strains tested were found to be able to transfer their genetic traits to $B$. subtilis by the mediation of phage S-1. Because the infective titer of the phage suspension prepared from $B$. natto was generally low, it was difficult to set the m.o.i. at the desired value.

Table 2. Transduction of try and arg markers in $B$. natto to B. subtilis $171-15$ by phage $\mathrm{S}-1$.

\begin{tabular}{|c|c|c|c|c|}
\hline \multirow{2}{*}{\multicolumn{2}{|c|}{ Donor }} & \multirow{2}{*}{ m.o.i. ${ }^{a}$} & \multicolumn{2}{|c|}{ Transductant No./plate } \\
\hline & & & $\arg ^{+}$ & $t r y^{+}$ \\
\hline \multirow[t]{7}{*}{ B. natto } & 1028 & 0.4 & 5,500 & 3,030 \\
\hline & 1212 & $10^{-3}$ & 2,736 & 2,616 \\
\hline & 1191 & $10^{-3}$ & 14,200 & 14,000 \\
\hline & 1259 & 0.5 & 444 & 48 \\
\hline & 1143 & $10^{-5}$ & 1,284 & 1,384 \\
\hline & 1109 & 1.0 & 0 & 0 \\
\hline & 1163 & $10^{-2}$ & 0 & 0 \\
\hline B. subtilis & 23 & 0.3 & 1,200 & 2,500 \\
\hline
\end{tabular}

a m.o.i; multiplicity of infection. $5 \times 10^{7}$ recipient cells were used.

In some strains, especially in 1191 and 1143, the frequency of transduction was considerably higher than that in $B$. subtilis 23 . This might have been due to the presence of larger numbers of defective phages. The reason why the defective phages are present so abundantly in $B$. natto lysates is not clear.

When $B$. subtilis 23 was used as a donor, the frequency in the transduction of try marker was about twice as high as that in the arg marker. On the other hand, the arg marker was transduced more frequently than the try marker when some strains of $B$. natto were used as donors.

Table 3. Transformation of $B$. subtilis $171-15$ by DNA from $B$. natto.

\begin{tabular}{|c|c|c|c|c|c|}
\hline & \multirow{2}{*}{\multicolumn{2}{|c|}{ Donor }} & \multirow{2}{*}{$\begin{array}{c}\text { DNA conc. } \\
\mu \mathrm{g} / \mathrm{ml}\end{array}$} & \multirow{2}{*}{$\frac{\text { Transformant }}{\arg ^{+}}$} & \multirow{2}{*}{$\frac{\text { No./plate }{ }^{a}}{t r y^{+}}$} \\
\hline & & & & & \\
\hline \multirow[t]{7}{*}{$B$. } & natto & 1028 & 0.1 & 13,000 & 15,000 \\
\hline & & 1212 & $" \prime$ & 12,500 & 10,400 \\
\hline & & 1191 & " & 13,200 & 9,950 \\
\hline & & 1259 & " & 600 & 500 \\
\hline & & 1143 & "I & 28,000 & 2,000 \\
\hline & & 1109 & " & 4,340 & 3,070 \\
\hline & & 1163 & " & 15,000 & 20,250 \\
\hline$B$. & subtilis & 23 & 0.01 & 4,970 & 4,300 \\
\hline
\end{tabular}

a $2 \sim 5 \times 10^{7}$ cells were used as recipients. 
Transformation from $B$. natto to $B$. subtilis

DNAs prepared from strains of $B$. natto were given to $B$. subtilis 171-15 $\left(t r y^{-} a r g^{-}\right)$. The frequencies are shown in Table 3. It is noteworthy that strains 1109 and 1163, which gave no transductant, were able to transform the recipient strains.

Transduction and transformation from $B$. subtilis to $B$. natto

Phages and DNA prepared from $B$. subtilis 23 were given to $B$. natto 1212-52 (try $\left.{ }^{-}\right)$and 1259-87 ( $\left.\mathrm{arg}^{-}\right)$. As shown in Table 4, in which the data

Table 4. Transduction and transformation from $B$. subtilis to $B$. natto and from $B$. natto to $B$. natto.

\begin{tabular}{|c|c|c|c|c|}
\hline \multirow{2}{*}{ Recipient } & \multirow{2}{*}{ Vector } & \multicolumn{3}{|c|}{ Donor } \\
\hline & & W23 & 1212 & 1259 \\
\hline $1212-52$ & $\mathrm{DNA}^{a}$ & $1400^{c}$ & 300 & 400 \\
\hline$t r y^{-}$ & S-1 0 & 40 & 104 & 130 \\
\hline $1259-87$ & $\mathrm{DNA}^{a}$ & 0 & 0 & 0 \\
\hline $\arg ^{-}$ & S-1" & 0 & 100 & 1150 \\
\hline
\end{tabular}

for transduction and transformation from $B$. natto to $B$. natto are also shown, the try marker in strain 1212-52 was transduced as well as transformed by the phage and DNA from 23, whereas the arg marker in strain 1259-87 was not. The absence of transduction and transformation in the latter may be ascribed to their low frequencies as seen in Tables 2 and 3.

\section{DISCUSSION}

As described above, the genetic similarity between $B$. subtilis and $B$. natto was evidenced by the results obtained by the transduction as well as transformation technique. It is still early to conclude, however, which of the results obtained by the two techniques may be regarded as more significant in discussing the taxonomic correlation between the two species in question. As far as the present experiments are concerned, the frequencies of transformation were comparatively constant regardless of the difference in donor strains and genetic markers, while the frequencies of transduction fluctuated significantly depending on the strains and markers used.

One significant point is the arg: try ratio as given in Table 2. As has been reported by TAKAGI (7), the ratio is invariably $1: 2$ when strain 23 is used as the donor. Meanwhile, the ratio obtained with strains of $B$. natto as 
donors was approximately $1: 1$, with an exception of the value $10: 1 \mathrm{ob}$ tained with strain 1259. This fact together with the observation that the phage from strain 1190 or 1163 could not transduce genetic traits to strain 171-15 although the DNA could cause transformation suggest that these two genetic events involves different mechanisms. Further disccussion on the problem will be made elsewhere in connection with the results obtained with other kinds of aerobic bacilli.

\section{SUMMARY}

Seven strains of $B$. natto investigated were found to be all vulnerable to phage S-l, while five among them were able to transfer their genetic traits to $B$. subtilis by the phage. All strains, including the two which could not transduce, were able to transform the genetic markers in $B$. subtilis by the DNA. The transduction as well as the transformation from $B$. subtilis to $B$. natto was also successful. Based on these results, the genetic similariy between $B$. subtilis and $B$. natto was discussed.

This work was partly supported by a Grant in Aid from the Ministry of Education.

\section{REFERENCES}

(1) S. Sawamura: Z. Physiol. Chem., 3, 351 (1879).

(2) C. L. Schldkraut, J. Marmur, and P. Doty: J. Mol. Biol., 3, 596 (1961).

(3) J. Marmur, E. Seaman, and J. Levine: J. Bacteriol., 83, 416 (1963).

(4) C. B. THORne: J. Bacterịol., 83, 106 (1962).

(5) I. TAKahashi: Biochem. Biophys. Res. Comm., 5, 171 (1961).

(6) J. Spizizen: Proc. Natl. Acad. Sci. USA, 44, 1072 (1958).

(7) J. TAKagi: J. Gen. Appl. Microbiol., 8, 216 (1962).

(8) H. SaIto and K. MiURA: Biochim. Biophys. Acta, 72, 619 (1963).

(9) H. SaIto, M. KohiYama, and Y. Ikeda: J. Gen. Appl. Microbiol., 7, 243 (1961). 